59, 107-111.

4. Hammond D.C. và Loffredo M. (2012). Breast reduction. Plast Reconstr Surg, 129(5), 829e-839e.

5. Kim D.H., Kim C.W., Lee J.W. và cộng sự. (2019). Distribution of internal thoracic artery perforators: A clincal anatomy study. Clin Anat, 32(4), 471-475.

6. Michelle le Roux C., Kiil B.J., Pan W.-R. và cộng sự. (2010). Preserving the neurovascular supply in the Hall-Findlay superomedial pedicle breast reduction: an anatomical study. Journal of Plastic, Reconstructive \& Aesthetic Surgery, 63(4), 655-662.

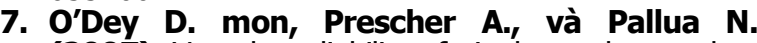
(2007). Vascular reliability of nipple-areola complexbearing pedicles: an anatomical microdissection study. Plast Reconstr Surg, 119(4), 1167-1177.

8. McGregor I.A. và Morgan G. (1973). Axial and random pattern flaps. Br J Plast Surg, 26(3), 202-213.

\title{
MộT Số YẾU TỐ LIÊN QUAN ĐẾN THỰC TRANG TRẦ CẢM CỦA NGƯỜI NHIỄM HIV/AIDS ĐANG ĐIỀU TRI ARV TÂI 2 PHÒNG KHÁM NGOẠI TRÚ TỈNH THÁI BÌNH
}

\section{TÓM TẮT}

Mục tiêu: Mô tả một số yếu tố liên quan đến trầm cảm của người nhiễm HIV/AIDS đang điêu trị ARV tai 2 phòng khám ngoại trú tỉnh Thái Bình năm 2019. Đối tượng nghiên cứu: bệnh nhân HIV/AIDS người lớn $\geq$ 18 tuổi (gọi tắt là người bệnh) đang điều trị ARV. Phương pháp nghiên cứu: Phương pháp mô tả thông qua cuộc điều tra cắt ngang. Kết quả nghiên cứu: yếu tố liển quan tới trầm của người nhiếm HIV đang điều trị ARV: thất nghiệp, lao động tự do $(\mathrm{OR}=3,4)$; làm việc bán thời gian hoặc theo mùa vụ $(\mathrm{OR}=5,3)$; thu nhập hàng tháng dưới 3 triệu đồng $(\mathrm{OR}=9,6)$; có sử dụng ma túy $(\mathrm{OR}=2,9)$; kinh tế hộ gia đình thuộc diện nghèo, không đủ ăn $(O R=7,5)$; không được hố trợ điều trị $(\mathrm{OR}=3,2)$; bị kỳ thị, phân biêt đối xử $(O R=4,0)$; găp phải tác dụng phụ của thuốc ARV $(\mathrm{OR}=2,5)$; đang điều trị các bệnh khác $(\mathrm{OR}=5,9)$; kết quả xét nghiệm $\mathrm{T}-\mathrm{CD} 4$ lần gần nhất > 500 tế bào $(\mathrm{OR}=2,5)$

Tư khóa: Yếu tố liên quan đến trầm cảm; HIV/AIDS; Thái Bình.

\section{SUMMARY \\ DEPRESSION SITUATION OF HIV/AIDS PATIENTS WHO TREATED HIV/AIDS WITH ARV AT 2 OUTPATIENT CLINICS IN THAI BINH PROVINCE}

Objectives: Describe related factors associated with depression of HIV/AIDS patients who treated HIV/AIDS with ARV at 2 outpatient clinics in Thai Binh province in 2019. Subjects: HIV/AIDS patients adults $\geq 18$ years old being treated with ARV. Method: Descriptive method through cross-sectional survey. Results: related factor of depression was: unemployment, self-employed $(\mathrm{OR}=3.4)$; working part-time or seasonally $(\mathrm{OR}=5,3)$; monthly income

*Trường Đại hơ Y Dược Thái Binh

Chịu trách nhiệm chính: Ngô Văn Mạnh

Email: manhsdh@gmail.com

Ngày nhận bài: 12.7.2021

Ngày phản biên khoa hoc: 30.8.2021

Ngày duyệt bài: 13.9.2021

\section{Ngô Văn Mạnh*, Bùi Thị Huyền Diệu*}

less than 3 million VND ( $O R=9.6)$; drug use $(O R=2.9)$; household economy is poor, not enough to eat $(\mathrm{OR}=7.5)$; no treatment support $(\mathrm{OR}=3.2)$; stigma, discrimination $(O R=4,0)$; experiencing ARV side effects $(O R=2.5)$; currently being treated for other diseases $(\mathrm{OR}=5.9)$; most recent $\mathrm{T}-\mathrm{CD} 4$ test result > 500 cells (OR $=2.5$ )

Keywords: Factors associated of depression; HIV/AIDS; Thai Binh

\section{I. ĐẶT VẤN ĐỀ}

Hơn 30 năm qua, kể từ khi phát hiện ra HIV cho đến nay, cộng đồng quốc tế đã nỗ lực rất lớn trong công tác chăm sóc, điều trị HIV/AIDS nhằm đẩy lùi sự gia tăng của đại dịch AIDS và đã thu được nhiều kết quả đáng ghi nhận đó là sự phát triển tổng thể của dịch AIDS toàn câu có vẻ như đã ổn định. Số người nhiễm mới HIV hàng năm giảm xuống đáng kể từ cuối những năm 1990 và tử vong liên quan AIDS ít dân do việc mở rộng điều trị kháng HIV.

Cùng với sự điều trị người bệnh HIV cũng được chăm sóc, hỗ trợ nhằm tăng cường sức khỏe thể chất. Tuy nhiển, khi sức khỏe thể chất được đảm bảo thì sức khỏe tâm thân của người nhiễm HIV cũng là một trong những vấn đề cân được quan tâm và can thiệp nhằm nâng cao hiệu quá điêuu trị cho họ. Người bệnh nhiễm HIV có thể gặp phải những ảnh hưởng tâm lý xã hội, các vấn đề sức khỏe tâm thân bắt đâu từ rất sớm ngay khi có chẩn đoán ban đâu và có thể phát sinh trong cả thời gian điêu trị bệnh. Các vấn đề phổ biến thường gặp phải là trâm cảm, lo âu và làm dụng các chất gây nghiện. Trong đó, trầm cảm là biến chứng thần kinh phổ biến nhất ở bệnh nhân nhiễm HIV và hạn chế đáng kể chất lượng cuộc sống của bệnh nhân HIV/AIDS [2].

Tại Việt Nam, các nghiên cứu đánh giá về vấn đề trầm cảm ở người bệnh nhiễm HIV đã được 
triển khai tại một số tỉnh nhưng hầu hết là các tỉnh thành lớn. Vì vậy chúng tôi tiến hành nghiên cứu đề tài với mục tiêu: Mô tả một số yếu tố liên quan đến thực trang mắc trầm cảm ở người nhiễm HIV/AIDS đảang điều trị ARV tại 2 phòng khám ngoại trú tỉnh Thái Bình năm 2019.

II. ĐỐI TƯợNG VÀ PHƯƠNG PHÁP NGHIÊN CứU 2.1. Địa điểm, thời gian, đối tượng nghiên cứu

- Địa điểm nghiên cứu: 02 phòng khám ngoại trú gồm: Phòng khám ngoại trú Bệnh viện Đa khoa thành phố Thái Bình và Phòng khám ngoại trú Bệnh viện Đa khoa huyện Kiến Xương

- Đối tượng nghiên cứu: Là bệnh nhân HIV/ AIDS người lớn $\geq 18$ tuổi (gọi tắt là người bệnh) đang điêu trị ARV tại 2 phòng khám nghiên cứu.

- Thời gian nghiên cứu: Nghiên cứu được thực hiện từ 10/2019 - 5/2020

\subsection{Phương pháp nghiên cứu}

2.2.1. Thiết kế nghiên cứu. Nghiên cứu mô tả thông qua cuộc điêuu tra cắt ngang.

2.2.2. Cỡ mẫu và phương pháp chọn mẫu

a/ Cõ̃ mẫu. Áp dụng công thức tính cỡ mẫu cho ước lượng một tỷ lệ:

$$
n=Z_{1-\alpha / 2}^{2} \frac{p \cdot(1-p)}{d^{2}}
$$

Với $Z=1,96 ; p=0,392$ (Theo nghiên cứu của Phạm Đình Quyết năm 2017, tỷ lệ người nhiếm HIV/AIDS mắc trầm cảm tại PKNT Gò Vấp là $39,2 \%[5] ; d=0,05$

Với các dữ liệu trên tính được $n=366$ bệnh nhân. Thực tế điều tra được 386 người bệnh đang điều trị ARV. b/ Phương pháp chọn mẫu: Tiến hành chọn chủ đích 02 phòng khám ngoại trú tại Bệnh viện Đa khoa Thành phố Thái Bình và Bệnh viện Đa khoa huyện Kiến Xương.

Tiến hành điều tra toàn bộ bệnh nhân điều trị tại 2 phòng khám đã chọn tại thời điểm nghiên cứu.

2.3. Phương pháp thu thập thông tin. Thông tin thu thập qua hồ sơ, bệnh án gồm các thông tin về tuân thủ điều trị, kết quả xét nghiệm T-CD4 lần gần nhất, tác dụng phụ của thuốc, bệnh lâm sàng kèm theo, giai đoạn lâm sàng hiên tai.

Thông tin định lượng được thu thập thông qua: phiếu phỏng vẩn trực tiếp người nhiễm HIV/AIDS đang điêu trị ARV tại đía bàn nghiên cứu được chọn để xác định các yếu tố liên quan đến trầm cảm

2.4. Các tiêu chuẩn sử dụng trong nghiên cứu. Đánh giá trầm cảm sử dụng thang đo Center for epidemiologic study depression scale (CES-D):

+ Trong từng câu hỏi, dấu hiệu hành vi được coi là "Có" nếu xuất hiện với tần suất từ "Đôi khi" đến "Rất hay xảy ra".

+ Phân loại dấu hiệu trầm cảm dựa theo tổng điểm của bộ câu hỏi CES-D20: Tổng điểm <16: không có dấu hiệu trầm cảm. Tổng điểm $\geq 16$ : có dấu hiêu trầm cảm.

2.5. Xử lý số liệu. Số liệu sau khi điều tra được làm sạch thô và nhập vào máy vi tính bằng phần mềm EPI-DATA, sau đó chuyển sang phần mềm SPSS 20.0 để xử lý với các test thống kề y học.

\section{KẾT QUẢ NGHIÊN CỨU}

Bảng 3.1. Môi liên quan giữa trầm cảm với nghề nghiệp và tính chất công việc $(n=386)$

\begin{tabular}{|c|c|c|c|c|c|c|c|c|}
\hline \multirow{2}{*}{\multicolumn{2}{|c|}{ Đặc điểm }} & \multicolumn{2}{|c|}{$\begin{array}{c}\text { Có trâm cảm } \\
(n=140)\end{array}$} & \multicolumn{2}{|c|}{$\begin{array}{l}\text { Không trầm } \\
\text { cảm }(n=246)\end{array}$} & \multicolumn{2}{|c|}{ Chung } & \multirow{2}{*}{$\begin{array}{l}\text { OR, } \\
\text { 95\%CI }\end{array}$} \\
\hline & & $\mathbf{S L}$ & $\%$ & $\mathbf{S L}$ & $\%$ & SL & $\%$ & \\
\hline \multirow{2}{*}{$\begin{array}{l}\text { Nghề } \\
\text { nghiệp }\end{array}$} & Thất nghiệp, lao động tự do & 129 & 40,3 & 191 & 59,7 & 320 & 82,9 & \multirow{2}{*}{$\begin{array}{c}3,4 \\
(1,7-6,7) \\
\end{array}$} \\
\hline & Nghề nghiệp ốn định & 11 & 16,7 & 55 & 83,3 & 66 & 17,1 & \\
\hline \multirow{2}{*}{$\begin{array}{l}\text { Tính chất } \\
\text { công việc }\end{array}$} & Công việc bán thời gian, mùa vụ & 82 & 52,2 & 75 & 47,8 & 157 & 40,7 & \multirow{2}{*}{$\begin{array}{c}5,3 \\
(3,2-8,9)\end{array}$} \\
\hline & Công việc toàn thời gian & 34 & 17,0 & 166 & 83,0 & 200 & 59,3 & \\
\hline
\end{tabular}

Kết quả bảng 3.1 cho thấy, tỷ lệ mắc trầm cảm ở nhóm bệnh nhân thất nghiệp, lao động tự do và nhóm làm việc bán thời gian là $40,3 \%$ và $52,2 \%$; nhóm này có nguy cơ mắc trâm cảm cao hơn nhóm có nghề nghiệp ổn định $(16,7 \%)$ và nhóm bệnh nhân làm việc toàn thời gian $(17 \%)$. Sự khác biệt này có ý nghĩa thống kê với OR lần lượt là 3,4 và 5,3

Bảng 3.2. Môi liên quan giữa trầm cảm với thu nhập hàng tháng và hành vi sử dụng ma túy $(n=386)$

\begin{tabular}{|c|c|c|c|c|c|c|c|c|}
\hline \multirow{2}{*}{\multicolumn{2}{|c|}{ Đặc điểm }} & \multicolumn{2}{|c|}{$\begin{array}{l}\text { Có trầm cảm } \\
(n=140)\end{array}$} & \multicolumn{2}{|c|}{$\begin{array}{l}\text { Không trầm } \\
\text { cảm }(n=246)\end{array}$} & \multicolumn{2}{|c|}{ Chung } & \multirow{2}{*}{$\begin{array}{c}\text { OR } \\
95 \% \mathrm{CI}\end{array}$} \\
\hline & & $\mathbf{S L}$ & $\%$ & SL & $\%$ & SL & $\%$ & \\
\hline & Có & 25 & 59,5 & 17 & 40,5 & 42 & 10,9 & 2,9 \\
\hline Sư dụng ma tuy & Không & 115 & 33,4 & 229 & 66,6 & 344 & 89,1 & $(1,5-5,6)$ \\
\hline
\end{tabular}




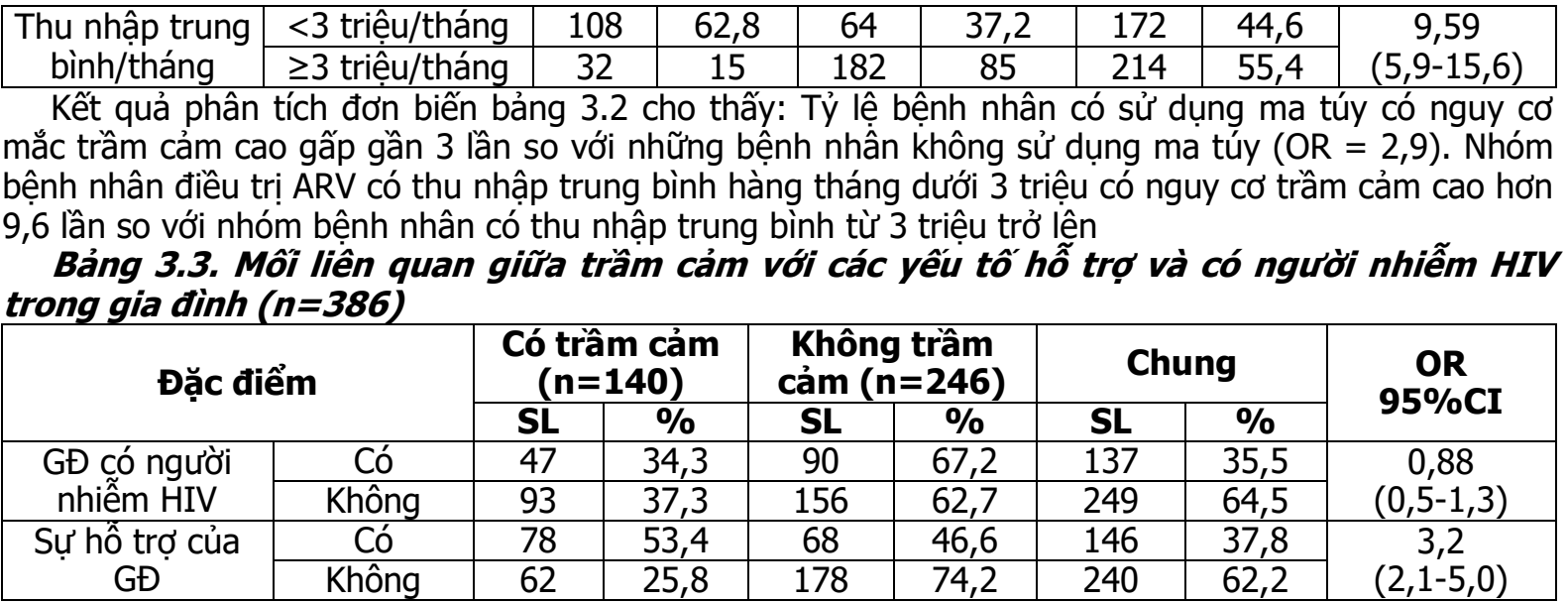

Qua bảng 3.3 cho thây: Chưa tìm thây mối liên quan giữa trầm cảm và việc gia đình có thêm người khác nhiễm HIV với $\mathrm{OR}=0,88, \mathrm{p}>0,05$.

Tỷ lệ bệnh nhân không được gia đình hố trợ bị trầm cảm là $53,4 \%$ và tỷ lệ bệnh nhân được hỗ trợ bị trầm cảm là $25,8 \%$. Người bệnh không được hỗ trợ có nguy cơ bị trầm cảm cao hơn gấp 3,2 lần so với bệnh nhân được hỗ trợ với $\mathrm{OR}=3,2, \mathrm{p}<0,05$

Bảng 3.4. Mối liên quan giữa trầm cám và sự kỳ thị $(n=386)$

\begin{tabular}{|c|c|c|c|c|c|c|c|}
\hline \multirow{2}{*}{$\begin{array}{l}\text { Bị kỳ thị̂, Trâm cảm } \\
\text { phân biệt đối xữ }\end{array}$} & \multicolumn{2}{|c|}{$\begin{array}{c}\text { Có trâm cảm } \\
(n=140)\end{array}$} & \multicolumn{2}{|c|}{$\begin{array}{l}\text { Khống trầm } \\
\text { cảm }(n=246)\end{array}$} & \multicolumn{2}{|c|}{ Chung } & \multirow{2}{*}{$\begin{array}{c}\text { OR, } \\
95 \% C I\end{array}$} \\
\hline & SL & $\%$ & SL & $\%$ & SL & $\%$ & \\
\hline Có & 89 & 54,6 & 74 & 45,4 & 168 & 43,5 & \\
\hline Không & 51 & 22,9 & 172 & 77,1 & 228 & 56,5 & $\begin{aligned} 4,0 \\
(26-6)\end{aligned}$ \\
\hline Chung & 140 & 100 & 246 & 63,7 & 386 & 100 & \\
\hline
\end{tabular}

Bảng 3.4 cho thấy tỷ lệ bênh nhân bị kỳ thi, phân biêt đối xử từ gia đình, cộng đồng hay tư chính họ thấy xấu hổ có nguy cơ bị trầm cảm cao hơn gấp 4 lần so với những bệnh nhân không gặp phải những vấn đề về kỳ thị hay phân biệt đối xử này với $\mathrm{OR}=4 ; 95 \% \mathrm{CI}: 2,6-6,2$.

Bảng 3.5. Mối liên quan giữa trâm cảm và kêt quả xét nghiệm T-CD4 lần gần nhất

\begin{tabular}{|c|c|c|c|c|c|c|c|}
\hline \multirow[t]{2}{*}{ Trâm cảm } & \multicolumn{2}{|c|}{$\begin{array}{c}\text { Có trâm cảm } \\
(n=140)\end{array}$} & \multicolumn{2}{|c|}{$\begin{array}{l}\text { Không trâm } \\
\text { cảm }(n=246)\end{array}$} & \multicolumn{2}{|c|}{ Chung } & \multirow{2}{*}{$\begin{array}{c}\text { OR, } \\
95 \% \mathrm{CI}\end{array}$} \\
\hline & SL & $\%$ & SL & $\%$ & SL & $\%$ & \\
\hline Không làm xét nghiệm & 64 & 40,0 & 96 & 60,0 & 160 & 41,5 & $2,5(1,3-4,6)$ \\
\hline Dưới 200 tế bào & 15 & 65,2 & 8 & 34,8 & 23 & 5,9 & $0,3(0,1-0,8)$ \\
\hline Từ 200 - 500 tế bào & 43 & 36,8 & 74 & 63,2 & 117 & 30,3 & $1,1(0,7-1,8)$ \\
\hline Trên 500 tế bào & 18 & 20,9 & 68 & 79,1 & 86 & 22,3 & 1 \\
\hline
\end{tabular}

Bảng 3.5 cho thấy: Những người không làm xét nghiệm có nguy cơ mằc trầm cảm cao gấp 2,5 lần so với những người có làm xét nghiệm có số lượng T-CD4 trên 500 tế bào $(O R=2,5 ; 95 \% C I: 1,3-4,6)$

Tỷ lệ \%

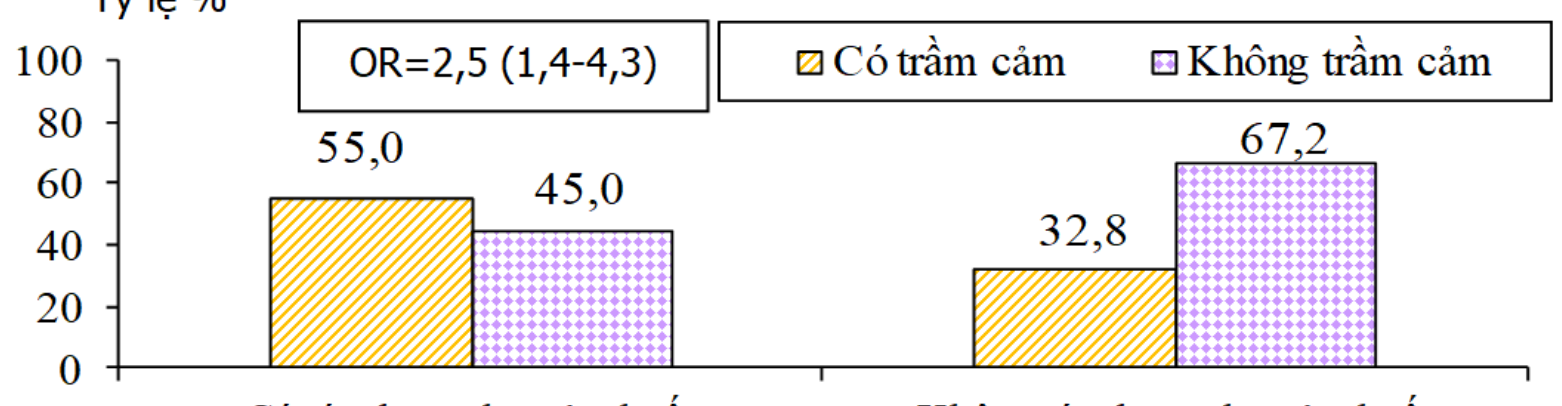

Có tác dụng phụ của thuốc

Không tác dụng phụ của thuốc

Biểu đồ 3.1. Môi liên quan giữa tràm cảm và tác dụng phụ của thuốc ARV (n=386) 
Qua kết quả biểu đồ 3.1 cho thãy, tỷ lệ bệnh nhân có bị tác dụng phụ của thuốc ARV mắc trầm cảm là $55 \%$; tỷ lệ bệnh nhân không có tác dụng phụ của thuốc ARV mắc trầm cảm là $32,8 \%$. Như vậy, những người gặp phải tác dụng phụ của thuốc có nguy cơ mắc trầm cảm cao gấp 2,5 lần so với những người không bị tác dụng phụ với $\mathrm{OR}=2,5 ; 95 \% \mathrm{CI}: 1,4-4,3$.

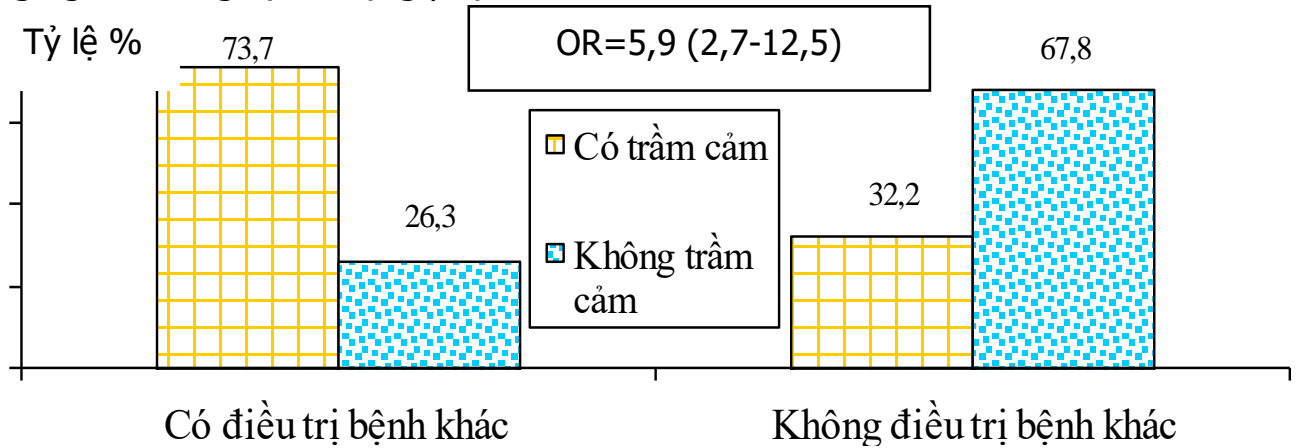

Biểu đồ 3.2. Môi liên quan giữa trầm cảm và tinh trạng sức khỏe (đang điều trị bệh khác) ( $n=386)$

Qua kết quả biểu đồ 3.2 cho thây: Trong số bệnh nhân đang điều trị ARV phải điều trị thêm bệnh khác có $73,7 \%$ mắc trầm cảm và $26,3 \%$ không mắc trầm cảm. Trong số bệnh nhân không điều trị bệnh khác có $32,2 \%$ có mắc trầm cảm và $67,8 \%$ không mắc trầm cảm. Như vậy, bệnh nhân có điều trị bệnh khác có nguy cơ mắc trầm cảm cao gấp 5,9 lần so với tỷ lệ bệnh nhân khổng điều trị bệnh khác với $O R=5,9(2,7-12,5)$.

\section{BÀN LUÂ̂N}

Chúng tôi thấy rằng các yếu tố sự ổn định của nghề nghiệp, thời gian làm việc toàn thời gian hay bán thời gian, làm việc theo thời vụ, thu nhập hàng tháng và hành vi sử dụng ma túy là các yếu tố liên quan đến tình trạng trầm cảm của người bệnh đang điều trị ARV. Điều này có thể là do sự bất an về kinh tế dẫn đến căng thẳng, thất vọng, cuộc sống gia đình rối loạn và cảm giác vô dụng. Những người này cũng có nhiều cơ hội phát triển, thực hiện hành vi nguy cơ cao. Thu nhập là yếu tố xã hội quan trọng quyết định sức khỏe của một người, nghiên cứu của chúng tôi tìm thây mối liên quan như sau: người bệnh có thu nhập trung bình hàng tháng thấp dưới 3 triệu đồng có nguy cơ mắc trầm cảm cao hơn những người có thu nhập trung bình từ 3 triệu trở lên gần 10 lần. Tỷ lệ này cao hơn so với nghiên cứu của Đặng Thị Minh Trang thực hiện tại Bình Dương chỉ có nguy cơ cao hơn 2,3 lần [4]. Có sư khác biệt này là do mức chênh lệch về sời sống của người dân Bình Dương và Thái Bình là khác nhau.

Yếu tố nguy cơ tiếp theo gây nên rối loạn trầm ở người bệnh đang điều trị ARV đó chính là hành vi sử dụng ma túy của họ. Mặc dù nhóm đối tượng nghiên cứu còn sử dụng ma túy không nhiêu chỉ có $9,8 \%$ nhưng nhóm này lại có nguy cơ mắc trầm cảm cao hơn nhóm không sử dụng ma túy tới 6 lần. Có nhiều giải thích có thể đưa ra như việc ho vốn có vấn đề về tâm lý, hoặc ở hướng ngược lại, trầm cảm có thể được xem là hậu quả của sinh lý của sử dụng 1 chất, ở đây là ma túy, khi đó ma túy được coi là bệnh sinh gây ra trâm cảm. Và dù có giải thích theo hướng nào thì việc tư vấn, điều trị, giới thiệu người bệnh tới các cở sở cai nghiện cũng cần được chú ý và thực hiện một cách hiệu quả.Yếu tố này chưa được nhắc đến nhiều trong các nghiên cứu trước đây, tuy nhiên đây có thể là một phát hiện mới nhằm cảnh báo nguy cơ đối với những người bệnh đang điều trị ARV mà vẫn đang sử dụng ma túy.

Những người có điều kiện kinh tế gia đình không đủ ăn, sống trong nghèo đói, không thể mua thực phẩm tốt cho sức khỏe, thiếu thốn quần áo và nhà ở tốt, tất cả đều là những điều kiện tiên quyết cần thiết để có sức khỏe tốt thì họ lại không có được. Khi đời sống gia đình khó khăn, họ có thể phải gánh chịu thêm cả những áp lực, những rối loạn tâm lý của người thân tác động tới họ. Những người này có nguy cơ bi trầm cảm cao hơn 7,5 lần so với người bệnh có điều kiện kinh tế gia đình khá giả, đủ ăn. Kết quả này cũng giống với kết quả Huỳnh Ngọc Vân Anh công bố năm 2017 nhưng tác giả này chỉ ra nguy cơ trầm cảm giữa 2 nhóm bệnh nhân thuộc hộ kinh tế khó khăn và khá giả là 1,53 lần [5], thấp hơn kết quả nghiên cứu của chúng tôi.

Hỗ trợ của gia đình và xã hội đối với người bệnh HIV/AIDS là rất quan trọng. Nó cung cấp sự ổn định về tinh thần, kinh tế và xã hội cho bệnh nhân. Nó cũng cung cấp sự ấm áp và chăm 
sóc cho bệnh nhân có nhu cầu và giảm các căng thẳng mà bệnh nhân phải đối mặt [6]. Tại Việt Nam, phần nào những rối loạn trầm cảm gặp phải ở người bệnh còn chưa được người thân và xã hội chú ý, điều này không chỉ gặp phải ở bệnh nhân đang điều trị ARV mắc trầm cảm mà còn ở người bệnh trầm cảm nói chung. Chúng tôi đã tìm thấy mối tương quan giữa việc hỗ trợ của người thân đối với người bệnh đang điều trị ARV và tình trạng trầm cảm của họ. Cu thể ở đây những người không nhận được sự hố trợ có nguy cơ mắc trầm cảm cao hơn những người được người thân hỗ trợ điều trị dù chỉ là vật chất hay tinh thần ( $95 \%$ CI: $2,131-5,088)$. Mối liên quan này cũng đã được tác giả Đặng Thị Minh Trang nhắc tới trong nghiên cứu tại Bình Dương của mình [4]. Hay trong một nghiên cứu cắt ngang thực hiện trên 100 người bệnh điêuu trị ARV ổn định tại Ấn Độ cũng đã khẳng định có mối liên quan giữa sự hỗ trợ của gia đình và tỷ lệ trầm cảm của người bệnh với $p=0,0002$ [7].

Mặc dù với các hoạt động tuyên truyền, chăm sóc điều trị hiện nay của ngành $Y$ tế nhằm giảm thiểu sự tác động tiêu cực về tinh thần và sức khỏe đối với người bệnh HIV thì việc kỳ thị, phân biệt đối xử đối với những người nhiếm HIV đã được giảm đi rất nhiều nhưng vẫn còn 1 bộ phận người bệnh gặp phải những vấn đề trên từ chính bản thân mình hoặc gia đình, nơi làm việc và cộng đồng. Đây cũng là một trong những yếu tố mà chúng tôi tìm ra có sự tương quan với tình trạng trầm cảm của ĐTNC. Kết quả đã chỉ ra những người bệnh lo lắng sẽ lây truyền HIV cho người khác hoặc chịu sự kỳ thị, phân biệt đối xử từ gia đình, xã hội, cộng đồng, nơi làm việc hay chính họ cảm thấy xấu hổ về tình trạng nhiễm của mình khiến họ có nguy cơ mắc trầm cảm cao hơn những người không phải chịu bất kỳ sự kỳ thị nào. Mối liên quan này cũng tương đồng với nghiên cứu tại Ethiopia của tác giả Tesachaw công bố năm 2016 với $95 \%$ CI: 2,23 - 5,80 [8].

Tuy nhiên, chúng tôi lại thây trầm cảm phổ biến hơn ở những bệnh nhân có tiền sử tác dụng phụ của thuốc điều trị ARV. Qua kết quả phân tích đơn biến cho thây người bệnh bị tác dụng phụ của thuốc ARV có khả năng trầm cảm cao hơn 2,5 lần so với những người không bị tác dụng phụ với $95 \% \mathrm{CI}: 1,431$ - 4,374. Điều này tương đồng với nghiên cứu tại Ethiopia kể trên có $95 \%$ CI: $1.317-16.514$ [8]. Với kết quả này, măcc dù HIV/AIDS không thể chữa khỏi, thuốc có thể giúp mọi người khỏe mạnh và ngành y tế đã có rất nhiêu thay đổi về phác đồ để cải thiện vấn đề tác dụng phụ và tăng hiệu quả điều trị ARV.
Nhưng vì các thuốc này có độc tính và tác dụng phụ bất lợi và tại Việt Nam có những thuốc ARV có tác dụng phụ gẩy ảnh hưởng tới sức khỏe người bệnh như gây thiếu máu, gây độc cho gan, thận hay gây hoang tưởng, ảo giác vẫn còn trong phác đồ điều trị của bệnh nhân chưa có thuốc nào có thể thay thế. Điều này khiến người bênh bị ảnh hưởng bởi tác dụng phụ của thuốc có tâm lý lo lắng, e sợ khi điều trị, đặc biệt là người bệnh mới điều trị thời gian ngắn hay những người đã chuyển qua nhiều phác đồ do ảnh hưởng bởi tác dụng phụ của thuốc. Những tác dụng phụ này cũng có thể làm gián đoạn các hoạt động, sinh hoạt hay công việc bình thường của người bệnh, do đó họ có thể cảm thấy vố vọng và phát triển trầm cảm. Và cũng có thể các triệu chứng trầm cảm có thể được kích hoạt bởi tác dụng phụ của thuốc điều trị ARV.

Ngoài ra, về yếu tố lâm sàng, chúng tôi cũng tìm thấy mối tương quan giữa việc người bệnh đang phải điều trị thêm bệnh khác ngoài HIV với tình trạng rối loạn trầm cảm của họ. Những người mắc thêm bệnh khác kèm theo có nguy cơ mắc trầm cảm cao hơn những người không phải điều trị bệnh gì khác tới gần 6 lần. Người nhiễm HIV là những bệnh nhân bị suy giảm miễn dịch và có khả năng mắc rất nhiều những bệnh nhiễm trùng cơ hội khác kèm theo do khả nằng chống chọi lại với bệnh tật của họ đã suy giảm. Những người này nểu mẳc thêm một bệnh khác, quá trình điều trị có thể sẽ dài hơn, hiệu quả điều trị sẽ kém hơn những người bình thường. Hơn ai hết họ là người hiểu rõ những vấn đề trên. Chính vì thế, khi họ mắc thêm 1 bệnh khác họ sẽ có sự lo lắng nhất định về sức khỏe của mình. Quá trình điêu trị kéo dài nhưng hiệu quả kém khiến ảnh hưởng tới tâm lý, sức khỏe và cả kinh tế của họ. Có thể đó là nguyên nhân khiến việc mắc bệnh kèm theo gây ra những biểu hiện rối loạn trầm cảm của người bệnh.

\section{KẾT LUÂN}

Yếu tố thất nghiệp, lao động tự do $(\mathrm{OR}=3,4)$; Làm việc bán thời gian hoặc theo mùa vụ $(\mathrm{OR}=5,3)$; Thu nhập hàng tháng dưới 3 triệu đồng $(\mathrm{OR}=9,6)$; Có sử dụng ma túy $(\mathrm{OR}=2,9)$; Kinh tế hộ gia đình thuộc diện nghèo, không đủ ăn $(\mathrm{OR}=7,5)$; Không được hố trợ điều trị $(\mathrm{OR}=3,2)$; Bị kỳ thị, phân biệt đối xử $(\mathrm{OR}=4,0)$; Gặp phải tác dụng phụ của thuốc ARV $(\mathrm{OR}=2,5)$; Đang điêu trị các bệnh khác $(\mathrm{OR}=5,9)$; Kết quả xét nghiệm $\mathrm{T}-\mathrm{CD} 4$ lần gấn nhất $>500$ tế bào $(\mathrm{OR}=2,5)$.

\section{KHUYẾN NGH!}


Cần có biện pháp hỗ trợ tâm lý người bệnh ngay từ sớm để làm giảm tỷ lệ trầm cảm của họ. Uu tiên cho nhóm đối tượng thu nhập thấp, không ổn định, đang điều trị bệnh khác, không có người hố trợ.

\section{TÀI LIÊU THAM KHẢO}

1. BMj Publishing Group (2018), Tổng quan về HIV, BMJ Best Practice.

2. Maria Giulia Nanni và các công sự (2015), "Depression in HIV infected patients: a review", Current psychiatry reports. 17(1), pp. 530.

3. Pham Đình Quyêt, võ Thị Duyên, Huỳnh Ngọc Vân Anh (2018), "Trầm cảm và các yếu tố liên quan ở ngưới nhiếm HIV/AIDS đang điêuu trị ARV", Tap chí Y học thành phố Hồ Chí Minh. 22(1), pp. 285-292.

4. Đăng Thị Minh Trang (2018), Rối loan trầm cảm trên người sống chung với HIV/AIDS đang điều trị ARV tại phòng khám ngoại trú Thuân An, Bình Dương, Hội nghị khoa học kỹ thuật lẩn thứ 35, Đai hoc $Y$ dược thành phố Hồ Chí Minh.

5. Huỳnh Ngọc Vần Anh (2017), Trầm cảm và các yêu tố liên quan ở những người nhiễm HIV điều trì ARV, Hội nghị khoa học kỹ thuật lần 34, Đại học Y Dược thành phố Hồ Chí Minh.

6. Bhatia. MS and Sahil Munjal (2014), "Prevalence of depression in people living with HIV/AIDS undergoing ART and factors associated with it", Journal of clinical and diagnostic research: JCDR. 8(10), pp. WC01

7. S. Algoodkar et al. (2017), "Prevalence and Factors associated with Depression among Clinically Stable People Living with HIV/AIDS on Antiretrovira Therapy", Indian J Psychol Med. 39(6), pp. 789-793

8. Tesfaw. G et al. (2016), "Prevalence and correlates of depression and anxiety among patients with HIV on-follow up at Alert Hospital, Addis Ababa, Ethiopia", BMC Psychiatry. 16(1), pp. 368.

\title{
HIỆU QUẢ CAN THIỆP CẢI THIÊ̂N TUÂN THỦ ĐIỀU TRI, ĐẠT HUYẾT ÁP MỤC TIÊU Ở BÊNNH NHÂN TĂNG HUYẾT ÁP TAI TRAM Y TẾ PHƯỜNG, QUậN THỦ ĐỨC, THÀNH PHỐ HỒ CHÍ MINH
}

\author{
Trần Quốc Cường*, Lê Văn Bào**, Nguyễn Anh Tuấn**
}

\section{TÓM TẮT}

Muc tiêu: Đánh giá hiêu quả can thiêp cải thiên tuân thủ điêu trị, đạt huyết áp mục tiêu ở bệnh nhẩn tăng huyết áp tại trạm y tế phường Linh Xuân, quận Thủ Đức, thành phố Hồ Chí Minh (2019 - 2020). Phương pháp: Mô tả cắt ngang; phỏng vấn đối tượng, khám lâm sàng, đo huyết áp; can thiệp điều trị THA, giáo duc, tư vấn về tuân thủ chế độ điều tri cho BN THA và đánh giá hiệu quả can thiệp. Kết quả: Tỷ lê tuân thủ chế đô̂ điêu tri như: uống thuốc, tái khám định kỳ, kiểm tra HA thường xuyên, chế độ ăn, uống, lối sônng (giảm mặn, tăng rau/củ/quả, giảm chất béo, giảm rượu/bia, ngưng hút thuốc, tập thể dục thường xuyên) đươợc cải thiện rõ rêt. Sự khác biệt về tỷ lệ tuân thủ các chế độ ở cả bốn thời điểm T3, T6, T12 và T18 so với T0 đều có ý nghĩa thống kê $(p<0,05)$. Tăng tỷ lệ BN đạt HA mục tiêu sau can thiệp 18 tháng (T18) lển 94,5\% (nữ: 98,1\% cao hơn nam: $90,0 \%$; nhóm BN <50 tuổi: 97,0\% cao hơn nhóm 50-59 tuổi: 96,6\% và nhóm 60-69 tuổi: 92,2\%). Kết luận: Tỷ lệ $B N$ tuân thủ các chế độ uống thuốc, tái khám đinh kỳ, kiểm tra HA thường xuyên, chế độ ăn, uống, lối sống được cải thiện rõ rệt. Tăng tỷ lẹ đạt HA mục tiêu sau can thiệp

*Trung tâm y tế dự phòng (CDC) Thành phố Thủ Đức, TP. Hồ Chí Minh

**Hoc viên Quân y

Chịu trách nhiệm chính: Trần Quốc Cường

Email: quoccuong.mph@gmail.com

Ngày nhận bài: 2.8 .2021

Ngày phản biên khoa hoc: 27.9.2021

Ngày duyệt bài: 4.10 .2021
18 tháng lên $94,5 \%$

Tư khóa: Can thiệp, tuân thủ điêu trị, huyết áp mục tiêu, trạm y tế.

\section{SUMMARY}

\section{EFFECTS OF INTERVENTION TO IMPROVE}

TREATMENT COMPLIANCE, ACHIEVE TARGET BLOOD PRESSURE IN HYPERTENSIVE PATIENTS AT HEALTH STATION OF WARD, THU DUC DISTRICT, HO CHI MINH CITY

Objective Evaluating the effectiveness of interventions to improve treatment adherence, achieve target blood pressure in hypertensive patients at the medical station of Linh Xuan ward, Thu Duc district, Ho Chi Minh city (2019 - 2020). Methods: Horizontal cut representation; subject interview, clinical examination, blood pressure measurement; hypertensive interventions, education, counseling on adherence to treatment regimens for hypertensive patients and assessment of intervention effectiveness. Results: The rate of adherence to treatment regimens such as: taking medications, periodic followup visits, regular blood pressure checks, diet, drinking, lifestyle (reducing salt, increasing vegetables/ vegetables/fruits, reducing fat, reducing alcohol) /beer, smoking cessation, regular exercise) improved markedly. The difference in the rate of adherence to the regimens at all four time points T3, T6, T12 and T18 compared with T0 was statistically significant $(p<0.05)$. Increase the rate of reaching target blood pressure after 18 months of intervention (T18) to $94.5 \%$ (female: $98.1 \%$ higher than male: $90.0 \%$; patient group $<50$ years old: $97.0 \%$ higher than the 